\title{
The Agreement between Serbia and Hungary on the Protection of National Minority Rights - Revision Welcomed
}

\author{
KATINKA BERETKA* \\ TAMÁS KORHECZ**
}

\begin{abstract}
This paper analyzes the bilateral agreement on the reciprocal protection of minorities that Serbia has signed with Hungary. The provisions of this agreement is examined, with the application of the legal-dogmatic, descriptive and comparative legal methods, and compared with the corresponding provisions in other bilateral agreements that Serbia has signed with neighboring countries, as well as with the provisions on the protection of the rights of persons belonging to national minorities as stated in the Constitution and laws of Serbia. The study pays special attention to the work of the mixed government commission; the state authorities' measures regarding the implementation of the agreement and the judicial protection. There is the formulation some recommendations through which this legal instrument could become a more effective legal remedy for the protection of national minorities. This analysis seeks an answer to the question of to what extent the bilateral agreement has contributed to the international and domestic legal framework for the legal protection of national minorities in Serbia, and whether it is today mainly a political instrument without particular legal relevance.
\end{abstract}

Keywords: bilateral agreements, Serbia, Hungary, national minorities rights, implementation of the international law.

\section{INTRODUCTION}

Bilateral agreements on the protection of the national minorities' rights have existed for a long time in international law. ${ }^{1}$ At the same time, their significance and role after the fall of the Berlin Wall have been particularly prominent in such continental developments. The bilateral international agreements in which the countries of the former 'Eastern Block' appear as contracting parties and which, in whole or partially, protect the rights of national minorities have notable distinguishing elements when compared to the bilateral agreements on the protection of minorities between the countries of Western Europe. ${ }^{2}$ Among the former socialist countries that have signed such agreements with almost all neighboring countries are Hungary and the Republic of Serbia (hereinafter: Serbia). Different reasons have led to these two countries having concluded such bilateral agreements. In the case of Hungary, one of the main reasons is that the Hungarian constitution established a responsibility of the state towards the millions of Hungarians who remained outside the borders of Hungary after the First World War, primarily in the neighboring countries. ${ }^{3}$ As far as Serbia is concerned, these bilateral agreements only became significant after the end of the warring conflicts on the territory of the former Socialist Yugoslavia, which led to its disintegration and the simultaneous emergence of new states containing new ethnic

* Faculty of Legal and Business Studies 'Dr Lazar Vrkatić,' Novi Sad, Union University, Serbia, beretka.katinka@gmail.com.

** Faculty of Legal and Business Studies 'Dr Lazar Vrkatić,' Novi Sad, Union University, Serbia, tkorhecz@tippnet.rs.

1 Gál (1999) 2-5.

2 Fiala-Butora (2004) 98-99.

3 Katona (2011) 123. 
majorities and national minorities. ${ }^{4}$ The $21^{\text {st }}$ century for Serbia ${ }^{5}$ began with the signing a series of such agreements with neighboring countries: Romania (2002), Hungary (2003), Macedonia (2004), and Croatia (2004). Such agreements were seen as critical to the success of the stabilization process and the new states' association with the European Union. ${ }^{6}$

Bilateral agreements cannot replace the international systems protecting the rights of national minorities within the United Nations and the Council of Europe. ${ }^{7}$ However, they potentially can serve as useful supplements. The legal regulation of the precise needs and challenges related to the protection and the position of a specific national minority represents the real potential of bilateral agreements. Mechanisms for direct consultations on current issues or monitoring conducted by mixed intergovernmental commissions can more flexibly, more precisely, and more efficiently resolve problems that might arise in the field of the national minority rights, i.e., in mutual political relations. ${ }^{8}$ This paper seeks an answer to the question of whether the bilateral agreement between Serbia and Hungary is such a legal instrument, worthy to complement the international and domestic legal framework for the protection of national minorities' rights.

The purpose of this paper is to analyze the Agreement on the Protection of the Rights of the Hungarian National Minority living in Serbia and Montenegro and the Serbian national minority living in the Republic of Hungary (hereinafter: Agreement); a bilateral agreement for the reciprocal protection of minorities, which the Republic of Serbia (then Serbia and Montenegro) signed with Hungary (then the Republic of Hungary) in 2003. ${ }^{9}$ The analysis will be carried out using the legal-dogmatic, the descriptive, and, in part, the comparative legal method so that some provisions of this Agreement will be compared with the corresponding provisions in other bilateral agreements that Serbia has signed with neighboring countries, as well as with the provisions on the protection of the rights of national minorities in the Constitution, laws, and other regulations of Serbia. Through this analysis, as well as through an analysis of the practical implementation of the Agreement and the work of the mixed intergovernmental commission for the implementation of the Agreement, the extent to which this Agreement has contributed to the improvement of the legal framework for the protection of national minorities will be establised and to what extent it has recognized the specific needs of Hungarians living in Serbia, as well as

4 Đurđević (2017) 22.

5 The first bilateral agreement has been signed by the Federal Republic of Yugoslavia, that had been transformed into the State Union of Serbia and Montenegro. Because of Montenegro's peaceful secession from the State Union the international legal subjectivity of the State Union of Serbia and Montenegro was inherited by the Republic of Serbia, that is, Serbia has become successor of international documents signed by the former Yugoslavia, in accordance with the Article 60 of the Constitutional Charter of the State Union of Serbia and Montenegro. Since 5 June, 2006, bilateral agreements in questions have been applying exclusively in bilateral relations between Serbia and the neighboring countries.

${ }^{6}$ Stabilisation and Association Agreement Between the European Communities and their Member States of the One Part, and the Republic of Serbia, of the Other Part (2008) Article 5.

7 Arp (2008) 76.

${ }^{8}$ Lantschner and Medda-Windischer (2000) 541.

9 Hungary has signed treaties of cooperation and good neighborly relations with Slovenia, Ukraine, Croatia, Romania and Slovakia almost one decade before Serbia (during the nineties), but 'against the background of international politics with particular regard to regional stability the problem of Hungarians living in Serbia was virtually neglected when the issue of bilateral treaties between Hungary and its neighbors was considered.' Bíró (1999) 372. 
Serbs in Hungary. The first part of the paper will provide a brief overview of bilateral agreements on minority protection which Serbia has signed with neighboring countries, as well as of the historical and political framework and the circumstances in which these agreements were created. In the second part, the provisions of the bilateral agreement between Serbia and Hungary will be presented and they will be compared with the provisions of other bilateral agreements between Serbia and neighboring countries as well as with the provisions of the Constitution and the laws of Serbia. The third part of the paper follows with an analysis of the implementation of the Agreement by the state authorities of Serbia, with special attention paid to the work of the mixed intergovernmental commission. In the fourth part of the work, concluding observations are offered along with the formulation of certain recommendations aimed at improving the bilateral protection of national minorities between Serbia and Hungary, since time intervals require continuous innovation of such instruments. ${ }^{10}$

\section{GENERAL OVERVIEW OF BILATERAL AGREEMENTS: HISTORY, POLITICAL CIRCUMSTANCES AND APPLICATION}

After the end of the conflicts in the territory of the former Socialist Yugoslavia and the fall of Slobodan Milosevic's regime that led to the international isolation of the Federal Republic of Yugoslavia (the Republic of Serbia and the Republic of Montenegro), postMilosevic Serbia initiated efforts towards international cooperation and European integration. Human rights were extensively violated in the civil wars of the former Socialist Yugoslavia during the 1990s, and these violations often had an ethnic dimension. The reintegration of the state into the international community demanded a firm commitment from the new state leadership to protecting national minorities and the development of good neighborly relations with the surrounding countries, which had often been burdened by the position of their dominant populations existing as national minorities in Serbia, a position Serbs as well occupied in neighboring countries. ${ }^{11}$ During the first decade of the $21^{\text {st }}$ century, the Federal Republic of Yugoslavia (from 2003, the State Union of Serbia and Montenegro) improved its constitutional and legal framework for the protection of national minority rights, ratifying the international conventions of the Council of Europe for the protection of the national minorities' rights and signed bilateral agreements on the reciprocal protection of minority rights with neighbors. ${ }^{12}$ The conclusion of the agreements of Serbia with neighboring countries on the reciprocal protection of the national minority rights (hereinafter: agreements) represented an important step in the improvement of neighborly relations and the overall interstate stability in the region. ${ }^{13}$ All agreements were adopted after the enactment of the then Law on the Protection of Rights and Freedoms of National Minorities (2002), whose provisions had a significant impact on the textualization of bilateral agreements, irrespective of the existence of certain structural, terminological, and somewhat substantive differences. Some provisions of the Framework Convention for the Protection of National Minorities were directly taken over by agreements, especially regarding the interpretation of the provisions of the agreements, while the number of countries/specific issues addressed by each was sporadic (the greatest amount of these occur

\footnotetext{
10 van der Stoel (2000).

11 Korhecz (2015) 74-75.

12 Korhecz (2019) 119.

13 See Huber and Mickey (1999) 17-51.
} 
in the agreement with Hungary, which is also the longest in number and greatest in complexity of the provisions). ${ }^{14}$

In the preamble of these bilateral agreements, there is a reference to the most relevant international documents on the rights of national minorities and the European Union is specifically mentioned (but in a different context) in the case of the agreement with the Republic of Croatia and Macedonia. ${ }^{15}$ Following the basic principles on the prohibition of discrimination, the guarantee of equality, the freedom of national determination, etc., are detailed the obligations of the contracting parties to the development of the rights of persons belonging to national minorities in regard to preserving their particular identity in the field of education, in the use of the mother tongue and personal names, in culture, in information, in religion, and in scientific and other research (in a different order). The right to maintain relations with a minority's country of origin and compatriots is guaranteed, i.e., the importance of cross-border cooperation is emphasized.

The agreements in question were concluded with the objective of protecting national minorities in the region, the Serbian national minority in the neighboring countries and other minorities of neighboring countries in Serbia, as defined in the agreement itself (except in the case of the agreement with Romania). As a rule, all guaranteed rights simultaneously belong to all national minorities living in the territory of the contracting parties on the basis of their assumed obligations stemming from ratified international agreements. ${ }^{16}$

The preamble of Serbia's agreement with Croatia and Macedonia starts by establishing that there is a Croatian, and, respectively, a Macedonian, national minority in Serbia and Montenegro and a Serbian and Montenegrin minority in the Republic of Croatia and the Republic of Macedonia, which are hereinafter jointly referred to as national minorities. In the agreement with Hungary, it is stated that the obligation of the contracting parties is to 'provide for the Hungarian national minority living in Serbia and Montenegro and for the Serbian minority living in Hungary (hereinafter: national minorities) preservation and development of their national, linguistic, cultural and religious identity;', 17 that is, "to support the activity of the National Council of the Hungarian National Minority in Serbia and Montenegro and the Self-Government of the Serbs in the Republic of Hungary.' ${ }^{\prime 18}$ The agreement with Romania, however, contains a solution that is not present in other agreements, offering the definition of a Romanian and Serbian national minority for the purpose of the agreement: 'as the Romanian national minority in the Federal Republic of Yugoslavia or the Serbian national minority in Romania will be deemed persons under their jurisdiction sharing common ethnic origin, language, and traditions within the majority population of the other contracting party. ${ }^{19}$ Such a definition is different from the concept

14 Beretka (2018) 266.

15 Declaratively the EU deems desirable for the acceding Central-East European countries - as potential candidates in the European integration - to make peace with each other, that is to recognize sovereignty one another within the new international political situation, and mutually guarantee territorial status one another (including problems in accordance with the population). Pataki (1994) 4.

16 These treaties provide rights mostly to individuals, but also communities as such might be recognized as right-holders. Thornberry (1994) 48.

17 Treaty between the Republic of Hungary and Serbia and Montenegro, on the Protection of Rights (2003) Article 1.

18 Treaty between the Republic of Hungary and Serbia and Montenegro, on the Protection of Rights (2003) Article 9. paragraph 3.

19 Treaty on Cooperation in the Field of National Minority Protection (2002) Article 1. 
of a national minority applied in the domestic law of Serbia, which, in addition to numerical representativeness and long-lasting and strong ties with the state territory, stipulates the possession of features such as language, culture, national or ethnic origin, or religion, according to which a particular group differs from the majority of the population. ${ }^{20}$

These agreements as well established special committees, mixed commissions from representatives of the contracting parties, including representatives of the national minorities protected by the agreements in question. Given that in the case of bilateral agreements, there is usually no supranational entity that controls the fulfillment of obligations by contracting parties. There is no obstacle for contracting parties to set up institutionalized control mechanisms of international organizations, or to include a third party in the role of supervisor in their bilateral relations, However, the mixed commissions should, inter alia, through providing information to the governments of the contracting parties, ensure the implementation of signed agreements and the exercise of the national minorities' rights from the agreement. ${ }^{21}$

Serbia signed the agreements in question with a validity period of five years (Romania, Hungary, Macedonia), except in the case of their agreement with Croatia, which was to remain valid for an indefinite period of time. If no contracting party were to inform the other party of its intention to terminate the agreement then it would be automatically extended for a period of three (Romania) or five years (Hungary, Macedonia). In the case of the agreements with Hungary and Macedonia, among the powers of the mixed commissions, it is particularly indicated that they are to offer recommendations to the governments of the contracting parties with regards to the modification of the agreement. It is worth noting that governments are not bound by these recommendations, or that such recommendations have not been formulated thus far. Mixed committees are more concerned with initiating the amendment of the national legislation (rather than amending the agreement) on disputed issues, especially regarding the political representation of minorities at all levels of government.

\section{LEGAL ANALYSIS OF THE BILATERAL AGREEMENT BETWEEN SERBIA AND HUNGARY PER THE COMPARATIVE LEGAL ANALYSIS}

Bilateral agreement between Serbia (then Serbia and Montenegro) and Hungary (then the Republic of Hungary) was signed on October 21, 2003 and ratified by the law adopted on June 15, 2004 in the Parliament of Serbia and Montenegro (hereinafter: Agreement). The Agreement contains a formal introduction and a total of 18 articles that cover the following sections: introductory provision (Article 1); the freedom of the national affiliation, the right to preserve identity, the prohibition of discrimination and assimilation (Article 2); expression, development, and preservation of ethnic, cultural, linguistic, and religious identity (Articles 3 to 7); participation in public life and self-government of minorities (Article 8 and 9); relations of the national minority with their compatriots abroad, public and private person assistance to minorities and their organizations from the home country (Article 10); economic development of areas where national minorities live, regional

20 Zakon o zaštiti prava i sloboda nacionalnih manjina, 11/2002, 1/2003 - Ustavna povelja, 72/2009, 97/2013, 47/2018, Article 2.

21 Gyurcsik (1998) 50. 
economic cooperation, border crossing (Article 11); the restitution of property that has been seized from national minorities and their ecclesial communities (Article 12); the conclusion of new bilateral agreements in other areas, the involvement of national minority representatives in the process of making new bilateral agreements, and respecting the provisions of the bilateral agreement on the protection of minorities when concluding such agreements (Article 13); provision of budget funds for the realization of obligations under the agreement (Article 14); interpretation of the agreement provisions in order to protect the achieved level of the national minorities' rights and the protection of the state sovereignty and territorial integrity of the contracting parties (Article 15); establishment of the Intergovernmental Mixed Commission for National Minorities with the participation of national minority members (Article 16); the final provisions on entry into force and the term of validity of the agreement (Article 17 and Article 18). ${ }^{22}$

In the next section of this paper, a more detailed analysis and comparison of the Agreement will be made in relation to the provisions regarding the right to express, develop, and preserve ethnic, cultural, linguistic, and religious identity (learning the mother tongue and education in the mother tongue, the right to preserve and develop culture, the right to use the language, the right to information and media). Within this analysis, the relevant provisions of the Agreement will be generally compared with the norms in Serbia's other bilateral agreements, as well as with the positive legal norms in domestic regulations in Serbia. $^{23}$

\subsection{Right to learn the mother tongue and education in the mother tongue}

Article 4 of the Agreement ensures to persons belonging to the national minorities institutionalized education in their mother tongues and the teaching of the mother tongues of the national minorities at all levels of education and the state shall ensure the operation of educational institutions which teach in the mother tongues of the national minorities and support the setting up of such institutions. The exercise of these rights shall be governed by the national legislation of the Contracting Parties.

This general provision of the Agreement has been specified in the manner that it prescribes that the Contracting Parties shall make possible and encourage the operation of state, religious and private educational institutions in which instruction can be organized entirely or partially in the mother tongue, or as fostering the mother tongue of the national minority; shall support initiatives of minority organizations, religious communities and parents, whose objective is education in one's mother tongue; shall lend support to the operation of faculties and language departments where the mother tongues of the national minorities are taught; shall support the employment of teachers from among the national minorities in educational institutions where classes are conducted in the mother tongue of the national minority. The Parties shall make possible the minorities to make use of state scholarships and fellowships, in particular for the education of teachers and theologues;

22 Although the Agreement between Serbia and Hungary provides for autonomy, avoids mentioning the principle of self-determination, disclaiming accusations of territorial claims, especially of Hungarians in Vojvodina. Jeszenszky (1996) 4.

${ }^{23}$ It's important to point out that the positive legal framework for the protection of national minority rights has been significantly elaborated, improved and completed since the conclusion of the bilateral agreement; comparison is made with the domestic legal provisions being valid at the beginning of 2019 . 
shall support mutual exchanges of students and lecturers; shall make possible the recruitment of teaching staff from the mother country in case there are not enough lecturers in the mother tongues of the national minorities and the terms of their engagement shall be jointly determined by the Contracting Parties; shall support the instruction of the language, culture and history of the national minority and its mother country and help in procuring books and teaching aids for these purposes; and shall encourage the dissemination and teaching of knowledge and teaching of the history and culture of the national minorities among the majority population.

There are some notable differences when comparing the provisions of the Agreement on education with other bilateral agreements on the protection of national minorities that Serbia has signed. In the agreements with Macedonia and Romania, provisions on education in the mother tongue are much softer and more general and quantitatively contain far fewer obligations than the agreement with Hungary. In contrast, the provisions contained in the agreement with Croatia are similar in volume, but different in substance, as they specifically regulate the obligation to obtain the prior opinion of the national minority association for the special curricula of the minority, the obligation of pedagogical documentation in the language of the minority, or the possibility of learning in the languages and alphabets of the national minority when teaching is conducted in the language of the majority, in those areas where the official use of the national minority language and alphabet is determined according to national regulations. ${ }^{24}$ This is not prescribed in other Serbia's bilateral agreements, nor in the Agreement with Hungary.

The following may be concluded if the provisions on education in the mother tongue of the Agreement are compared with similar provisions in the Constitution and the relevant laws in Serbia: the Constitution of Serbia ${ }^{25}$ in Article 79 guarantees members of national minorities the right 'to study in their own language in state institutions and institutions of autonomous provinces' as well as for 'the establishment of private educational institutions.' These rights of national minorities are exercised 'in accordance with the law,' which implies a relatively broad freedom of the legislator in making the implementation of these rights concrete and regulated by law. In particular, the Constitution does not provide for the possibility of churches and religious communities to establish schools for education in the mother tongue of national minorities, nor does it allow the exchange of teachers, lecturers, and pupils. On the other hand, the Constitution contains special provisions that stipulate that 'Serbia encourages a spirit of tolerance and intercultural dialogue' 26 and that Serbia is 'to encourage understanding, appreciation and respect for differences that exist due to the specific ethnic, cultural, linguistic, or religious identity of its citizens. ${ }^{27}$ Regarding the legislative framework, a comparative legal analysis of the interstate agreement provisions on education has been compared with the relevant provisions of the following laws: the Law on the Protection of the National Minorities Rights and Freedoms, the Law on the Foundations of the System of Education and Upbringing, ${ }^{28}$ the Law on Preschool

${ }^{24}$ Treaty on the Protection of the Rights of the Serbian and Montenegrin Minority in the Republic of Croatia (2004) Article 3.

25 Ustav Republike Srbije, 98/2006.

26 Ustav Republike Srbije 98/2006, Article 81.

27 Ustav Republike Srbije 98/2006, Article 48.

28 Zakon o osnovama sistema obrazovanja i vaspitanja, 88/2017, 27/2018. 
Education, ${ }^{29}$ the Law on Primary Education, ${ }^{30}$ the Law on Secondary Education, ${ }^{31}$ the Law on Textbooks, ${ }^{32}$ and the Law on Higher Education. ${ }^{33}$

When it comes to preschool, primary, and secondary education, regardless of some differences in terminology, the provisions of the relevant laws and obligations of the state referred to in paragraph 1 of Article 4 of the Agreement are largely aligned and harmonized. More specifically, sectoral laws on the education of national minority members regulate issues in considerably more detail and cover items that are not covered by the provisions of the Agreement (such as keeping pedagogical records and issuing public documents in the language of a national minority). At the same time, there are some differences in the sense that some rights and obligations from the Agreement are not regulated by sectoral laws. Firstly, education in the mother tongue of a national minority in accordance with the constitution and sectoral laws is ensured in educational institutions founded by the state (the Republic, autonomous province, or local self-government unit); that is, only those institutions that are financed from the budget. Private and religious institutions where teaching is conducted in the language of a national minority are not financed by the state budget, although such an option is indirectly prescribed by the Agreement. Likewise, the positive domestic law does not recognize the possibility of exchanging lecturers, that is, engaging teachers from the kin state in the event of a lack of teachers teaching in the language of the national minority, nor does it support the employment of teachers in education in the mother tongue of the national minority. At the same time, some sectoral laws prescribe the keeping of records on the national affiliation of employees in educational institutions, which enables the practical realization of such measures. ${ }^{34}$ When it comes to higher education, the distinction between the provisions of the law and the Agreement is quite noticeable. Namely, the relevant legal provisions do not oblige higher education institutions to provide studies in the language of a national minority, nor prescribe special budgetary funds to aid the realization of such programs. A positive sectoral law only allows the accreditation of such programs, with corresponding decisions taken by the authorities of the higher education institution. Only the Law on the Protection of the National Minorities Rights and Freedoms prescribes certain positive obligations of the state in relation to higher education; in Article 14 it is stipulated that 'for the purposes of education in the language of national minorities ... the development of study programs for teachers in the languages of national minorities will be supported with the law governing higher education.'

Based on the above comparative analysis, it can be concluded that certain provisions of the Agreement extend the obligations of Serbia in securing the rights of Hungarians in Serbia in the field of education, and thus, as lex specialis, enable the undertaking of special affirmative measures to ensure the specific needs of the Hungarian national minority in Serbia.

${ }_{29}$ Zakon o predškolskom vaspitanju i obrazovanju, 18/2010, 101/2017, 113/2017, 95/2018.

30 Zakon o osnovnom obrazovanju i vaspitanju, 55/2013, 101/2017, 27/2018.

31 Zakon o srednjem obrazovanju i vaspitanju, 55/2013, 101/2017, 27/2018.

32 Zakon o udžbenicima, 68/2015.

33 Zakon o visokom obrazovanju, 88/2017, 27/2018, 73/2018.

34 Zakon o osnovama sistema obrazovanja i vaspitanja, Article 179; Zakon o predškolskom vaspitanju i obrazovanju, Article 7a. 


\subsection{The right to preserve and develop culture}

Regarding the protection and development of culture, the intergovernmental agreement regulates these rights in Article 3. According to this provision: persons belonging to the national minorities shall have the right, both individually and in community with other members of their group, to freely express, preserve and develop their ethnic, cultural, linguistic and religious identity.

The Contracting Parties shall pay special attention to the meeting of cultural needs of the national minorities. They shall provide conditions necessary for the functioning of cultural centers; shall provide assistance in supplying, on a non-commercial basis, books, magazines, artistic publications, audio-visual materials, exempt from customs duties and other charges, aid an independent publishing industry of the national minorities, guest performances of their professional and amateur ensembles and organization of all cultural and artistic events aimed at enriching the culture and identity of the national minorities; shall co-operate in the protection of historical monuments and cultural heritage related to the culture and history of the national minorities; and shall create conditions necessary for the national minorities to preserve their material and architectural monuments and other works of art that are part of their cultural heritage and tradition.

Comparing the provisions of the Agreement on the protection of the culture of national minorities with those of other bilateral agreements on the protection of national minorities that Serbia signed, there are no significant differences but the Agreement between Serbia and Hungary is again somewhat more concrete and more comprehensive. An interesting solution is found in the agreement with Macedonia, where it is stated that the preservation of the cultural heritage of national minorities will be regulated by a special (interstate) agreement between the contracting parties, ${ }^{35}$ and in the agreement with Hungary which establishes The Program for the Protection and Preservation of the Cultural Heritage of Minorities with the participation of representatives of minority self-governments and other minority organizations. ${ }^{36}$

It can be concluded from the provisions of the Agreement regarding culture with similar provisions in the Constitution and relevant laws in Serbia that the Constitution of Serbia does not detail specific obligations of the state regarding the preservation and development of the culture of national minorities, with the exception that it mentions the culture of national minorities in the context of the right to preserve and express their own culture, the establishment of cultural associations, and self-government in the field of culture. According to the Constitution, the state's competence is divided between Serbia, the Autonomous Province of Vojvodina, and local self-government units. ${ }^{37}$ Regarding the legislative framework, a comparative legal analysis of the provisions on culture of the interstate agreement with the relevant provisions has been performed on the following laws: the Law on the Protection of National Minorities Rights and Freedoms, the Law on Culture, ${ }^{38}$ and the Law on Cultural Property. ${ }^{39}$ The Law on the Protection of the National

35 Treaty between the Republic of Macedonia and Serbia and Montenegro on the Protection..., Article 6.

36 Treaty between the Republic of Hungary and Serbia and Montenegro, on the Protection..., Article 3 paragraph 3.

37 See Ustav Republike Srbije, Article 97, 183 and 190.

38 Zakon o kulturi, 72/2009, 13/2016, 30/2016.

39 Zakon o kulturnim dobrima, 71/1994, 52/2011, 99/2011. 
Minorities Rights and Freedoms in Article 12 regulates in detail the right to cultivate the culture and traditions of a national minority, broadly guarantees the possibility of establishing associations and institutions of culture whose goal is to cultivate and protect the culture of a national minority, and, in the case of cultural institutions (archives, institutions for the protection of monuments, museums) founded by the Republic of Serbia, the Autonomous Province of Vojvodina and the local self-government unit prescribe specific obligations regarding the representation and protection of the cultural heritage of the national minority. According to Article 6 of the Law on Culture (the overarching-sectoral law in this area), the general interest in the field of culture includes, inter alia, 'discovering, creating, studying, preserving, and representing ... the culture of national minorities in the Republic of Serbia.' Article 24 of this law states that 'The Republic of Serbia, the autonomous province and the local self-government unit may establish institutions for the preservation, promotion, and development of cultural specialties and the preservation of the national identity of national minorities.' Article 16 stipulates that the national minority representatives participate in the work of central bodies in the field of culture and, per Article 20, their cultural creativity is part of the strategy of the Republic of Serbia for the development of culture. Unlike the previous two laws, the Law on Cultural Property, which was adopted in the early 90s, does not recognize the cultural property of national minorities or the obligations of the state in relation to them. This does not preclude the application of this law to the cultural heritage of a national minority, but at the same time it does not establish special guarantees in this respect.

Comparing the specific obligations of the Agreement with the provisions of the laws in the field of culture, it can be concluded that they are compatible and that the agreement in some areas represents a special legal basis for the protection of minority culture. This is especially expressed in the obligation to help cultural centers of national minorities, ${ }^{40}$ in exempting from taxes donations to national minorities in the form of books, audio visual materials, etc., as well as in the possibility for states to cooperate and specifically finance the preservation of cultural monuments of importance for the culture of national minorities.

\subsection{Right to use the mother tongue}

The interstate agreement in Article 5 regulates the rights regarding the use of the languages of national minorities. According to this article, persons belonging to the national minorities shall be entitled, both individually and in community with other members of their group, to freely, without any restrictions, use their mother tongue in oral and in written communication, in private and public life. In addition to this general provision, the agreement contains some specific obligations of the state regarding the use of the language of a national minority by members of national minorities, so that:

- the Contracting Parties shall commit themselves to recognizing in their national legislation the right of persons belonging to the national minorities to use their first and family names in their mother tongues and scripts in their personal identification documents, official records and personal databases. The issuance of personal documents to persons belonging to the national minorities in their mother tongues shall be governed by the regulations of the Contracting Parties;

40 Cultural centers of national minorities are not constitutional or legal category, but in practice they usually seem to be the most important folklore association in a village or region. 
- persons belonging to the national minorities shall be entitled, in accordance with the national legislation and in places they inhabit traditionally or in substantial numbers, to the use of their mother tongues in proceedings before official bodies - including proceedings before public administration bodies and before courts of law. In these proceedings, persons belonging to the national minorities shall be entitled to obtain information in their mother tongues in the shortest possible period of time and, if necessary, with the free assistance of an interpreter;

- the bodies of the minority self-government shall be entitled to conduct their business also in their mother tongue;

- in areas inhabited by persons belonging to the national minorities in substantial numbers or of a particular cultural significance to them, the Contracting Parties shall, in accordance with their national legislation, make it possible for the national minorities to display, in the mother tongue and according to its orthography, the names of towns, streets and other public places, as well as topographical indications, inscriptions and information in public places;

- persons belonging to the national minorities shall have the right to publicly display in their mother tongue nameboards of enterprises, inscriptions and other information of a private nature.

If the provisions of the Agreement between Serbia and Hungary on the use of national minority languages are compared with other bilateral agreements on the protection of national minorities that Serbia has signed, there are no significant differences in relation to the agreements with Macedonia and Romania, except that the agreement with Hungary contains a provision on the issuance of public documents and keeping records. ${ }^{41}$ The Croatian agreement's use of language is rather complex, and perhaps this is the only area that is regulated in more detail than in the agreement with Hungary. Unlike the agreement with Hungary, it is specifically stipulated that the contracting parties shall ensure the use of languages in the work of representative and executive bodies of local self-government units, in the process of conducting state and local elections and referenda, and in the compilation of private documents used in legal transactions, using bilingual forms, nameplates, stamps and seals of state bodies, bodies of local self-government units, and legal entities that have public authority. ${ }^{42}$

A comparison of the provisions on the use of language in the Agreement between Serbia and Hungary with the relevant provisions of the Constitution and laws in Serbia can be summarized by the following statements. The Constitution of Serbia guarantees the general right of national minority members to use their own language and alphabet. ${ }^{43}$ At the same time, a large number of constitutional provisions regulate the official use of language and alphabet. Thus, Article 10 of the Constitution provides that 'Serbian language and Cyrillic script shall be in official use in the Republic of Serbia but the law based on the Constitution might regulate official use of other languages and scripts. ${ }^{, 44}$ A large number of the constitution's provisions contain guarantees regarding the use of language in the course of apprehension and judicial and other proceedings, of which Article 199 should be especially emphasized. This guarantees to each person (not only members of national

41 Treaty between the Republic of Hungary and Serbia and Montenegro, on the Protection..., Article 5 paragraph 2.

42 Treaty on the Protection of the Rights of the Serbian and Montenegrin Minority..., Article 6.

43 Ustav Republike Srbije, 98/2006 Article 79(1)

${ }^{44}$ Ustav Republike Srbije, 98/2006 Article 10(2) 
minorities) the right to use their language in proceedings regarding some of their rights or obligations (regardless of whether the language of the proceedings is understood). On the other hand, the official use of the language of national minorities is specifically regulated by the provisions in Article 79 of the Constitution. According to this provision, 'members of national minorities shall have a right to have proceedings also conducted in their languages before state bodies, organizations with delegated public powers, bodies of autonomous provinces and local self-government units, in areas where they make a significant majority of population.' In the same article, national minorities are guaranteed 'use of their name and family name in their language; traditional local names, names of streets, settlements and topographic names also written in their languages, in areas where they make a significant majority of population... in compliance with the law.'

Regarding the legislative framework, a comparative legal analysis was performed on the provisions on the use of language of the intergovernmental agreement with the relevant provisions of the following laws: the Law on the Protection of the National Minorities Rights and Freedoms, the Law on Official Use of Language and Alphabet Letters, ${ }^{45}$ the Law on Registry Books, ${ }^{46}$ the Law on General Administrative Procedure, ${ }^{47}$ the Law on Misdemeanors, ${ }^{48}$ the Code of Criminal Procedure, ${ }^{49}$ the Civil Procedure Law, ${ }^{50}$ the Company Law, ${ }^{51}$ the Law on the Election of Members of Parliament, ${ }^{52}$ the Law on Local Elections, ${ }^{53}$ and the Law on National Councils of National Minorities Councils. ${ }^{54}$

Based on the analysis of Serbia's legal framework regarding the use of the national minority language, it can be concluded that the use of the language of national minorities, especially in the public sphere, is regulated in detail by a large number of laws. Positive regulations are not only aligned with the obligations of the Agreement regarding the use of the Hungarian language but provide a significantly higher level of protection. Thus, among other things, the Law on the Official Use of Language and Alphabet as well as the Law on the Protection of the National Minorities Rights and Freedoms, in accordance with Articles 10 and 79 of the Constitution, enable the language of the national minority to be introduced in official use if the percentage of the national minority in the total population of one unit of local self-government reaches $15 \%$; what is more, the official use of the language and alphabet of the national minority is enabled even if the percentage of population is significantly below $15 \%$.

In practice, the official status of the Hungarian language is recognized in many areas where the percentage of Hungarians does not even reach 5\%. Hungarian is the official language, totally or partially, in 31 out of 45 local self-government units in the territory of

45 Zakon o službenoj upotrebi jezika i pismama, 45/1991, 53/1993, 67/1993, 48/1994, 101/2005, 30/2010, 47/2018, 48/2018.

46 Zakon o matičnim knjigama, 20/2009, 145/2014, 47/2018.

47 Zakon o opštem upravnom postupku, 18/2016.

48 Zakon o prekršajima, 65/2013, 13/2016, 98/2016.

49 Zakonik o krivičnom postupku,72/2011, 101/2011, 121/2012, 32/2013, 45/2013, 55/2014.

50 Zakon o parničnom postupku, 72/2011, 49/2013, 74/2013, 55/2014, 87/2018.

51 Zakon o privrednim društvima, 36/2011, 99/2011, 83/2014, 5/2015, 44/2018.

52 Zakon o izboru narodnih poslanika, 35/2000, 57/2003, 72/2003, 75/2003, 18/2004, 101/2005, 85/2005, 28/2011, 36/2011, 104/2009.

53 Zakon o lokalnim izborima, 129/2007, 34/2010, 54/2011.

54 Zakon o nacionalnim savetima nacionalnih manina, 72/2009, 20/2014, 55/2014, 47/2018. 
AP Vojvodina, ${ }^{55}$ where Hungarians traditionally live. ${ }^{56}$ The volume of linguistic rights enabling members of national minorities, if their language is recognized as an official language, provides significantly more extensive rights than those provided for in Article 5 of the Agreement. Thus, it is possible to conduct first instance judicial and administrative proceedings in the official language of a national minority. ${ }^{57}$ It is possible to use the language of the national minority in the work of elected assemblies at the local, provincial, and state level, ${ }^{58}$ election material is printed in the language of the national minority ${ }^{59}$ and company names and other public inscriptions are in the official language of the national minority (not only the possibility of this). ${ }^{60}$ According to the Agreement, the rights related to the use of the language of national minorities in judicial and administrative procedures are limited to places where members of national minorities live traditionally and in large numbers, whereas the positive regulations of Serbia extend that right to the entire territory of the state. ${ }^{61}$ The laws also allow the use of Hungarian to communicate with all state institutions, regardless of their headquarters, and that the parliament members use the Hungarian language in the work of the National Assembly. ${ }^{62}$

At the end of this analysis, it should be noted that the only provision of the Agreement which until 2018 was not stipulated by the laws of Serbia is the provision on the use of the language of the national minority in the work of the national council - the right to conduct the affairs of the national minority self-government in the language of the national minority. This guarantee was incorporated in the Law on National Councils of National Minorities by the amendments of 2018, but even before this, the right was not questionable in practice or on the basis of other regulations. The conclusions from this comparative legal analysis are that the standards of the Agreement in the field of the right to use the Hungarian language are below the standard of the use of the Hungarian language according to relevant sectoral laws and that they do not contain any provision that would expand, define, or add to the existing legal framework.

\subsection{Right to information and the media}

Article 6 of the interstate agreement stipulates the rights to information and media. According to this Article, Serbia shall recognize the right of the national minorities to access to the media and to the creation and management of their own media outlets, as well as, the right of the national minorities to have access to information in their mother tongues in the press, on the radio, television and other electronic means of public information. These general provisions of the state are further defined in accordance with their national legislation, the Contracting Parties shall make it possible to produce and regularly broadcast programs in the mother tongue on the radio or television in an appropriate length and at

55 According to the official website of the Provincial Secretariat for Education, Regulations, Administration and National Minorities - National Communities, http://www.puma.vojvodina.gov.rs/ etext.php?ID_mat=207 accessed 3 May 2019.

${ }^{56}$ Hungarians traditonally have been living in the AP Vojvodina, which territory had been part of the Hungarian Kingdom for centuries.

57 Zakon o službenoj upotrebi jezika i pisama, Article 12(2).

58 Zakon o zaštiti prava i sloboda nacionalnih manjina, Article 11(4).

59 Zakon o lokalnim izborima, Article 28(7); Zakon o izboru narodnih poslanika, Article 60(6).

${ }^{60}$ Zakon o službenoj upotrebi jezika i pisma, Article 20(1).

61 Zakon o službenoj upotrebi jezika i pisma, Article 16-17.

62 Zakon o zaštiti prava i sloboda nacionalnih manjina, Article 11(8)-(12). 
appropriate times, while taking into account the territorial distribution of the national minorities; facilitate the reception and broadcasting of radio and television programs from the mother country; and support information activities of the national minorities.

Comparing the provisions of the Agreement between Serbia and Hungary on information and the media with other bilateral agreements on the protection of national minorities that Serbia has signed shows that there are no significant differences, except that the agreement with Hungary contains a provision on access to information in the mother tongue in other electronic means of public information, apart from radio and television. ${ }^{63}$ In the agreement with Croatia, it is particularly emphasized that the contracting parties materially assist the informative activity of minorities, while in the Agreement with Hungary, the term support is used in the same provision. Taking into account the donations Hungary provides to media in the Hungarian language in Serbia, it can be concluded that in practice, in the relations between Hungary and Serbia, material assistance is certainly implied.

The comparison of the provisions on information and the media of the Agreement between Serbia and Hungary with similar provisions in the Constitution and relevant laws in Serbia leads to the following conclusion. In addition to the general guarantees regarding the freedom of the media and information, the Constitution of the Republic of Serbia, in Article 79, contains a special provision on the right to information of national minorities members: 'Members of national minorities shall have a right to... complete, timely and objective information in their language, including the right to expression, receiving, sending and exchange of information and ideas; establishing their own mass media, in compliance with the law.' Constitutional provisions have been defined by the Law on the Protection of the National Minorities Rights and Freedoms, the Law on Public Information and the Media, ${ }^{64}$ the Law on Public Media Services, ${ }^{65}$ and the Law on Electronic Media. ${ }^{66}$ These laws define the information in the languages of national minorities as a public interest, enable the establishment of media in the languages of national minorities, provide for a specific model of financing them from state budget funds, and regulate the special obligations of the public media service to broadcast programs in the languages of national minorities. According to the Law on Public Information, it is in the public interest that 'public information is, among other things, true, impartial, timely, and complete in the mother tongue of the citizens of the Republic of Serbia belonging to national minorities,' as is 'the preservation of the cultural identity of the Serbian people and national minorities living in the territory of the Republic Serbia.' ${ }^{67}$

Realizing the public interest is also facilitated by enabling the national minorities councils to establish institutions and companies in order to exercise the right to public information in the language of a national minority or foundations in order to achieve a generally useful goal of improving public information in the language of the national minority in accordance with the law. ${ }^{68}$ The same law stipulates certain obligations regarding the budgetary financing of the media in the language of national minorities:

63 Treaty between the Republic of Hungary and Serbia and Montenegro, on the Protection of Rights..., Article 6, paragraph 2.

${ }^{64}$ Zakon o javnom informisanju i medijima, 83/2014, 58/2015, 12/2016.

65 Zakon o javnim medijskim servisima, broj 83/2014, 103/2015, 108/2016.

${ }^{66}$ Zakon o elektronskim medijima, 83/2014, 6/2016.

67 Zakon o javnom informisanju i medijima, Article 15.

68 Zakon o javnom informisanju i medijima Article 16. 
'In order to enable the realization of the rights of national minorities to inform in their own language and foster their own culture and identity, the Republic of Serbia, the autonomous province, or the local self-government unit shall provide part of the funds, through co-financing or other conditions, for the media that publish information in the languages of national minorities through the authority in charge of public information.' ${ }^{6}$ For projects submitted to any competition that is being published in order to raise the quality of information of national minority members, the opinion of the relevant national council of the national minority is mandatory. ${ }^{70}$ The provision that enables regular financing (not project-program) from public revenues of media in the language of the national minority, whose founder is the national council of the national minority, ${ }^{71}$ is of particular importance. The obligation of the privatized local media to provide continuity in the period of 5 years when it comes to the program's share that is broadcast in the language of the national minority is also important. ${ }^{72}$ Per the provisions of the Law on Electronic Media, one of the basic tasks of an independent regulatory body for electronic media is to encourage the preservation and protection of Serbian culture and languages, as well as the culture and languages of national minorities. ${ }^{73}$ It is worth stating that some of the highest representatives of this body are representatives of national minority councils. ${ }^{74}$

According to the Law on Public Media Services, the public interest satisfied by the public media service is, inter alia, 'satisfying citizens' needs for program contents that ensure the preservation and expression of the cultural identity of both Serbian and national minorities, taking into account that national minorities follow certain program units in their mother tongue and alphabet. ${ }^{75}$

From a comparative analysis of the relevant positive law in the field of information, it can be concluded that the laws of Serbia fulfill the standard of the Agreement and regulate the matter of information in the language of the national minority in relation to the bilateral agreement.

\section{ANALYSIS OF THE APPLICATION OF THE BILATERAL AGREEMENT BETWEEN SERBIA AND HUNGARY: INTERGOVERNMENTAL MIXED COMMISSION, CONSTITUTIONAL COURT, ACTION PLAN}

\subsection{Intergovernmental mixed commission}

The Agreement between Serbia and Hungary provides a special mechanism for monitoring and implementation through the Intergovernmental Mixed Commission for National Minorities (henceforth: Intergovernmental Commission). This intergovernmental commission is composed of an equal number of representatives of Serbia and Hungary, appointed by the governments, with the mandatory involvement of representatives of the Hungarian self-government in Serbia and Serbs from Hungary. The Intergovernmental

69 Zakon o javnom informisanju i medijima Article 13.

70 Zakon o javnom informisanju i medijima, Article 24(2).

71 Zakon o javnom informisanju i medijima, Article 143.

72 Zakon o javnom informisanju i medijima, Article 142.

73 Zakon o elektornskim medijima, Article 22.

74 Zakon o elektornskim medijima, Article 9.

75 Zakon o javnim medijskim servisima, Article 7. 
Commission is obliged to meet as necessary, but at least once a year, adopts its decisions with the consent of both contracting parties, and is competent to discuss current issues regarding the position of national minorities and the fulfillment of obligations under the agreement and to propose to the governments measures regarding the application or amendments of the Agreement. ${ }^{76}$

In the period of 15 years since the ratification of the Agreement, the Intergovernmental Commission has held only five sessions; the first in December 2004 in Budapest, the second in November 2005 in Subotica, the third in May 2009 in Andrevlje, the fourth in June 2011 in Budapest, and the fifth and final session in April 2016 in Subotica. It is clear that these meetings of the Intergovernmental Commission have not been held annually, as required by the Agreement, but rather infrequently, at times with a period of four or five years between two sessions. What makes the mechanism for implementing the agreement through the Intergovernmental Commission additionally questionable is that the minutes detailing the recommendations of the Intergovernmental Commission are often not even considered by the corresponding authorities. ${ }^{77}$ According to the available data, the Government of Serbia, unlike the Government of Hungary, did not consider the minutes of the Intergovernmental Commission meeting at its sessions, nor did it adopt an act on the acceptance and implementation of recommendations. However, a content analysis of the minutes of the Intergovernmental Commission meetings indicates that a number of issues were discussed in these sessions regarding the position of minorities and the fulfillment of obligations under the agreement. Apart from the many remarks and mentions of proposals that had made significant progress after the previous Intergovernmental Commission meeting, ${ }^{78}$ there are open questions continually repeated in the minutes without any progress being made. Amongst the recommendations that have been made to the Serbian contingent are:

1. The improvement in the conditions for the official use of the Hungarian language in state institutions,

2. exemption from taxes for Hungarian donations to the Hungarian national minority,

3. the equalizing of diplomas obtained in Hungary,

4. measures to increase the number of Hungarian judges in the judiciary,

5. measures to increase the number of Hungarians in border police,

6. special compensation to pedagogists who teach in the Hungarian language,

7. the return of church property and assistance for churches,

8. the resolving of financing of private dormitories from the budget,

9. the establishment of educational centers for Hungarians in Novi Sad and Zrenjanin,

10. support for the protection of Hungarian historical monuments in Vojvodina,

11. broadcasting in the Hungarian language programs of Radio-Television of Vojvodina across the entire territory of the province. ${ }^{79}$

76 Treaty between the Republic of Hungary and Serbia and Montenegro, on the Protection of Rights..., Article 16.

77 Perković (2016) 20.

78 Some of the issues that were discussed during the Intergovernmental Commission meetings meanwhile have been solved, such as the enactment of the Law on National Minority Councils, financing of the activity of the Hungarian National Council from the state budget, opening new border crossings between Serbia and Hungary and the foundation of the Teacher Training Faculty in the Hungarian Language in Subotica.

79 See Minutes of the Intergovernmental Commission meetings at 2004, 2005, 2009, 2011 and 2016 sessions. 
It can be concluded that at the meetings of the Intergovernmental Commission a number of current issues regarding the implementation of the Agreement were considered but that the implementation mechanism was rather inefficient due at least in part to the nonsubmission of recommendations to the competent authorities through the acts of the respective government. ${ }^{80}$ The Intergovernmental Commission has never formulated recommendations to governments to amend or supplement the Agreement, despite having explicit jurisdiction in this regard.

\subsection{The Action Plan for the Realization of National Minorities' Rights and the Intergovernmental Agreement}

In the process of negotiating full membership in the European Union, the Government of Serbia adopted a special Action Plan for the Realization of the Rights of National Minorities in 2016 as one of the special prerequisites for opening chapter 23 negotiations. ${ }^{81}$ Chapter 11 of the Action Plan states that in connection with the existing bilateral agreements, the biggest problem is the realization, since the joint sessions of the bilateral commissions are not held according to the planned dynamics, and it is difficult to monitor the implementation of joint decisions.' Among the activities are, inter alia, the renewal of the existing bilateral commissions for national minorities (activity 11.1.), providing conditions for the regular meetings of intergovernmental commissions (activity 11.4.) and the adoption of a special conclusion for reporting of the Government on agreed measures and activities in the implementation of bilateral agreements (activity 11.5.). According to the latest report of the Office for Human and Minority Rights on the implementation of the Action Plan, almost all planned activities have been successfully implemented. They are continuously realized in relation to the development of bilateral relations in the field of national minority rights but most of the measures are only of a formal character e.g., holding a session of intergovernmental commissions, the appointment of state representatives in intergovernmental commissions, participation in the work of international organizations. ${ }^{82}$

\subsection{Judicial protection of rights from the intergovernmental agreement between Serbia and Hungary in Serbia}

The provisions of the Serbian Constitution state that the courts make their decisions on the basis of the Constitution, laws, and other general acts, when stipulated by law they should respect the generally accepted rules of international law and ratified international treaties. ${ }^{83}$ Yet in resolving legal disputes, courts in Serbia rarely base their decisions on the provisions of the Constitution or international agreements. The courts usually make their decisions based on laws and by-laws issued on the basis of the law, and on classical, written sources of domestic law. In line with this practice, there are not examples of regular courts basing their judgments regarding the rights of the Hungarian national minority in Serbia on the provisions of this Agreement.

The Constitutional Court is somewhat different. In some of its important decisions, the Constitutional Court has indeed listed specific bilateral agreements on the reciprocal

80 Tóth (2011) 58-62.

${ }^{81}$ Akcioni plan za ostvarivanje prava nacionalnih manjina (2015).

${ }^{82}$ Izveštaj o sprovođenju Akcionog plana za ostvarivanje prava nacionalnih manjina, (2018) $569-85$.

83 Ustav Republike Srbije, Article 142(2). 
protection of minorities among the relevant legal sources for the settlement of the constitutional legal dispute ${ }^{84}$ but on the specific provisions of the same agreements, it has only exceptionally based its decision. A rare exception in this regard is one decision of the Constitutional Court rendered in the normative control of the constitutionality and legality of the Statute of Backa Topola, a local self-government in the north of Serbia populated mainly by Hungarians. The Constitutional Court rejected the initiative to declare illegal and unconstitutional the provisions of the Statute (Article 2 and Article 3) which stipulated the official use of traditional names of settlements in the Hungarian language in the municipality of Backa Topola. In its decision, the Constitutional Court also referred to the Agreement between Serbia and Hungary on the protection of minorities. According to the reasoning of the Constitutional Court, this right is stipulated in Article 5, paragraph 5 of the Agreement, and the provisions of the Agreement under Article 194 of the Constitution prevail over the provisions of the Law on the Official Use of Languages and Alphabet, ${ }^{85}$ which at that time restricted the use of traditional names of settlements in the language of national minorities. ${ }^{86}$

\section{CONCLUDING CONSIDERATIONS}

Bilateral agreements on national minority rights, and therefore the Agreement between Serbia and Hungary, were concluded to a greater extent with the purpose of demonstrating the good will of the contracting parties and to a lesser extent of amending the legal framework for the reciprocal protection of specific national minorities. ${ }^{87}$ For this very reason, many provisions of these agreements are too general and require special elaboration in laws. The Agreement between Serbia and Hungary, unlike other agreements, covers almost all aspects of the protection of the national minority while also containing some very specific provisions that complement the general legal framework for the protection of national minorities in Serbia. A comparative legal analysis of this Agreement's provisions was made in relation to the positive law of Serbia, finalizing it with the situation overview at the beginning of 2019. This analysis found that most of the provisions of the Agreement were not only elaborated upon and implemented by laws and other regulations between 2004 and 2019 but the standards of protection from the Agreement were also enhanced by the laws of Serbia. Today, the Agreement does not constitute an additional guarantee, and in a way its content has been mainly depleted. At the same time, some of the guarantees and rights of the Agreement have yet to be assumed by Serbia's regulations, such as budget aid and the financing of non-state educational institutions, employment of teachers from the country of origin, exemption from fees and grants for minorities from the country of origin, etc. Concerning the implementation of the Agreement through the Intergovernmental Commission and the courts in Serbia, significant shortcomings were noted regarding both the regularity of the Intergovernmental Commission meetings and the lack of measures to implement the recommendations from the minutes of the Intergovernmental Commission meetings. However, these shortcomings have been noted and stated in the Serbian government's Action Plan, and, therefore, some progress in these matters is expected.

Although there are no obstacles, neither the Advisory Committee of the Council of Europe's Framework Convention, the Intergovernmental Commission, nor the Action Plan

84 Odluka Ustavnog suda Srbije, 20/2014.

85 Odluka Ustavnog suda Srbije, 35/2010, $5,7$.

86 Zakon o službenoj upotrebi jezika i pisama, Article 7(3).

87 Report on the Preferential Treatment of National Minorities by their Kin-State (2001). 
foresee a change to the exact text of the Agreement between Serbia and Hungary (as well as other bilateral agreements). However, that there are indeed sufficient reasons to do so. The provisions of the Agreement could be amended as follows: the obligations under the Agreement should be more precisely and thoroughly defined in accordance with the needs of a particular national minority by detailing specific institutions and specific cultural monuments and specifying the forms of financial assistance from the home state and their exemption from taxes and duties on donations. This is all towards the purpose of making the Agreement adaptable to the specific needs of protected national minorities, of terminologically and substantially harmonizing the provisions of the Agreement with the already well-coded terminology in the sectoral and system laws of Serbia and of regulating in greater detail the procedural issues pertaining to the work of mixed commissions so as to increase their effectiveness.

\section{LITERATURE}

Arp, B., International Norms and Standards for the Protection of National Minorities: Bilateral and Multilateral Texts with Commentary (Martinus Nijhof Publishers 2008)

Beretka, K., 'Bilateralni ugovorni odnosi Srbije sa susednim državama u oblasti zaštite prava nacionalnih manjina' (2018) 12 Pravni život 263-79.

Bíró, G., 'Bilateral Treaties of Hungary and its Neighbors after 1989' in Ignác Romsics and Béla K. Király (eds) Geopolitics in the Danube Region: Hungarian Reconciliation Efforts, 1848-1998 (Central European University Press 1999) 347-78.

Đurđević, N. (ed), National Minorities in Serbia's Relationship with the Neighbours. The Status of National Minorities in Serbia and EU Negotiations: The Role of Neighbouring Countries Belgrade (Forum for Ethnic Relations 2017).

European Commission for Democracy Through Law (Venice Commission), Report on the Preferential Treatment of National Minorities by their Kin-State, Venice, 19-20 October 2001 $<$ http://www.venice.coe.int/webforms/documents/default.aspx?pdffile=CDL-INF(2001)019-e> accessed 19 April 2019.

Fiala-Butora, J., Bilateral Treaties on Minority Protection in Europe (LLM thesis, Central European University 2004).

Gál, K., Bilateral Agreements in Central and Eastern Europe: A New Inter-State Framework for Minority Protection? (European Centre for Minority Issues 1999).

Gyurcsík, I., 'Basic Treaties, Minority Issues and the Enlargement of the European Union' (casestudies: Hungary, Romania, Slovakia) (1998) Regio 9-68.

Huber, K. and Mickey, R. W., 'Defining the Kin-state: An Analys es of its Role and Prescriptions for Moderating its Impact' in Arie Bloed and Piter van Dijk (eds), Protection of Minority Rights through Bilateral Treaties: The Case of Central and Eastern Europe (Springer Netherlands 1999) $17-51$.

Jeszenszky, G., 'Hungary's Bilateral Treaties with the Neighbours and the Issue of Minorities' (1996) 4 Ethnos und Nation.

Kancelarija za ljudska i manjinska prava, Izveštaj 1/2018 o sprovođenju Akcionog plana za ostvarivanje prava nacionalnih manjina, 569-85 <http://www.ljudskaprava.gov.rs/sites/default/ files/dokument_file/izvestaj_1-2018.pdf $>$ accessed 19 April 2019.

Katona, F., ‘A magyar-szlovák alapszerződés másfél évtized távlatából', (2011) tavasz Pro Minoritate 123.

Korhecz, T., 'Evolving legal framework and history of national minority councils in Serbia' (2019) 2 International Journal of Public Law and Policy 116-37.

Korhecz, T., 'National Minority Councils in Serbia' in Tove H. Malloy, Alexander Osipov, and Balázs Vizi (eds) Managing Diversity through Non-Territorial Autonomy: Assessing Advantages, Deficiencies and Risks (Oxford University Press 2015) 69-91. 
Lantschner, E. and Medda-Windischer, R., 'Protection of National Minorities through Bilateral Agreements in South Eastern Europe', (2000) 1 European Yearbook of Minority Issues Online $535-61$.

Max van der Stoel, 'Minority Rights, Participation and Bilateral Agreements - Address to an international seminar on Legal Aspects of Minority Rights: Participation in Decision-Making Processes and Bilateral Agreements on Minority Rights' (2000) <https://www.osce.org/ henm/42346?download=true $>$ accessed 16 April 2019.

Minutes of the Intergovernmental Mixed Commission Mixed Commission for National Minorities between Serbia and Hungary meetings at 2004, 2005, 2009, 2011 and 2016 sessions.

Pataki, G. Zs., 'Az alapszerződések stratégiai háttere: kényszer és kompromisszum, avagy az euroatlanti integráció lehetősége’ (1996) 4 Magyar Kisebbség.

Perković, J. (ed), Analiza sprovođenja bilateralnih sporazuma o zaštiti prava nacionalnih manjina Srbije sa Hrvatskom, Mađarskom, Rumunijom i Makedonijom (Centar za regionalizam 2016).

Stabilisation and Association Agreement Between the European Communities and their Member States of the One Part, and the Republic of Serbia, of the Other Part, 29 April $2008<\mathrm{https}$ ://ec. europa.eu/neighbourhood-enlargement/sites/near/files/pdf/serbia/key_document/saa_en.pdf $>$ accessed 17 April 2019.

Thornberry, P., International Law and the Rights of Minorities (Clarendon Press, Oxford 1994).

Tóth, J., 'A kisebbségek kulturális jogai Magyarországon a nemzetközi vállalások tükrében (2011) 1 Kisebbségkutatás $47-72$.

Vlada Republike Srbije, Akcioni plan za ostvarivanje prava nacionalnih manjina <http://www. ljudskaprava.gov.rs/sh/node/21793> accessed 26 April 2019.

\section{LEGISLATION AND OTHER LEGAL SOURCES}

Odluka Ustavnog suda Srbije, IU-446/2004 od 18. februara 2010. godine, Službeni glasnik RS, $35 / 2010$.

Odluka Ustavnog suda Srbije, IUz-882/2010 od 16. januara 2014. godine, Službeni glasnik RS, 20/2014.

Treaty between the Republic of Hungary and Serbia and Montenegro, on the Protection of Rights of the Hungarian Minority Living in Serbia and Montenegro and the Serbian Minority Living in the Republic of Hungary, signed at Belgrade on 21 October 2003.

Treaty between the Republic of Macedonia and Serbia and Montenegro on the Protection of the Macedonian National Minority in Serbia and Montenegro and Protection of the Serbian National Minority in the Republic of Macedonia, signed at Skopje on 6 July 2004.

Treaty on Cooperation in the Field of National Minority Protection between the Federal Government of the Federal Republic of Yugoslavia and the Government of Romania, signed at Belgrade on 4 November 2002.

Treaty on the Protection of the Rights of the Serbian and Montenegrin Minority in the Republic of Croatia and of the Croatian Minority in Serbia and Montenegro, adopted between Serbia and Montenegro and the Republic of Croatia, signed at Belgrade on 15 November 2004.

Ustav Republike Srbije (Constitution of the Republic of Serbia), Službeni glasnik RS, 98/2006.

Ustavna povelja Državne zajednice Srbija i Crna Gora (Constitutional Charter of the State Union of Serbia and Montenegro), Službeni list SCG, 1/2003, 26/2005 - Amandmani I-III.

Zakon o elektronskim medijima (Law on Electronic Media), Službeni glasnik RS, 83/2014, 6/2016.

Zakon o izboru narodnih poslanika (Law on the Election of Members of Parliament), Službeni glasnik $R S, 35 / 2000,57 / 2003,72 / 2003,75 / 2003,18 / 2004,101 / 2005,85 / 2005,28 / 2011,36 / 2011$, $104 / 2009$.

Zakon o javnim medijskim servisima (Law on Public Media Services), Službeni glasnik RS, broj 83/2014, 103/2015, 108/2016.

Zakon o javnom informisanju i medijima (Law on Public Information and the Media), Službeni glasnik $R S, 83 / 2014,58 / 2015,12 / 2016$.

Zakon o kulturi (Law on Culture), Službeni glasnik RS, 72/2009, 13/2016, 30/2016. 
Zakon o kulturnim dobrima (Law on Cultural Property), Službeni glasnik RS, 71/1994, 52/2011, 99/2011.

Zakon o lokalnim izborima (Law on Local Elections), Službeni glasnik RS, 129/2007, 34/2010, $54 / 2011$.

Zakon o matičnim knjigama (Law on Registry Books), Službeni glasnik RS, 20/2009, 145/2014, $47 / 2018$.

Zakon o nacionalnim savetima nacionalnih manina (Law on National Councils of National Minorities Councils), Službeni glasnik RS, 72/2009, 20/2014, 55/2014, 47/2018.

Zakon o opštem upravnom postupku (Law on General Administrative Procedure), Službeni glasnik $R S, 18 / 2016$.

Zakon o osnovama sistema obrazovanja i vaspitanja (Law on the Foundations of the System of Education and Upbringing), Službeni glasnik RS, 88/2017, 27/2018.

Zakon o osnovnom obrazovanju i vaspitanju (Law on Primary Education), Službeni glasnik RS, 55/2013, 101/2017, 27/2018.

Zakon o parničnom postupku (Civil Procedure Law), Službeni glasnik RS, 72/2011, 49/2013, 74/2013, 55/2014, 87/2018.

Zakon o predškolskom vaspitanju i obrazovanju (Law on Preschool Education), Službeni glasnik RS, 18/2010, 101/2017, 113/2017, 95/2018.

Zakon o prekršajima (Law on Misdemeanors), Službeni glasnik RS, 65/2013, 13/2016, 98/2016.

Zakon o privrednim društvima (Company Law), Službeni glasnik RS, 36/2011, 99/2011, 83/2014, $5 / 2015,44 / 2018$.

Zakon o službenoj upotrebi jezika i pismama (Law on Official Use of Language and Alphabet Letters), Službeni glasnik RS, 45/1991, 53/1993, 67/1993, 48/1994, 101/2005, 30/2010, 47/2018, $48 / 2018$.

Zakon o srednjem obrazovanju i vaspitanju (Law on Secondary Education), Službeni glasnik RS, 55/2013, 101/2017, 27/2018.

Zakon o udžbenicima (Law on Textbooks), Službeni glasnik RS, 68/2015.

Zakon o visokom obrazovanju (Law on Higher Education), Službeni glasnik RS, 88/2017, 27/2018, $73 / 2018$.

Zakon o zaštiti prava i sloboda nacionalnih manjina (Law on the Protection of the National Minorities Rights and Freedoms), Službeni list SRJ, 11/2002; Službeni list SCG, 1/2003 - Ustavna povelja; Službeni glasnik RS, 72/2009, 97/2013, 47/2018.

Zakonik o krivičnom postupku (Code of Criminal Procedure), Službeni glasnik RS, 72/2011, 101/2011, 121/2012, 32/2013, 45/2013, 55/2014. 